\title{
Effect of UV-C irradiation and heat treatment on the shelf life stability of a lemon-melon juice blend: multivariate statistical approach
}

\author{
Zehra Kaya, Semanur Yıldız, Sevcan Ünlütürk* \\ Department of Food Engineering, Izmir Institute of Technology, Urla, Izmir 35437, Turkey
}

\section{A R T I C L E I N F O}

\section{Article history:}

Received 11 December 2014

Received in revised form 1 February 2015

Accepted 2 March 2015

Available online 19 March 2015

\section{Keywords:}

UV-C irradiation

Heat treatment

Melon juice

Shelf-life

Principal component analysis (PCA)

Hierarchical cluster analysis (HCA)

\begin{abstract}
A B S T R A C T
Heat treatment and UV-C irradiation of lemon and melon juice (LMJ) blends were comparatively evaluated by examining their impact on E. coli K12 (ATCC 25253) and their physicochemical properties, i.e., total soluble solids (TSS), pH, titratable acidity (TA), color, turbidity and absorbance coefficient, both immediately after processing and during 30 days of refrigerated storage. The newly formulated LMJ blend containing $12 \%$ (v/v) lemon juice $(\mathrm{pH} 3.92 \pm 0.01)$ scored the highest in the consumer acceptance test. Upon UV-C irradiation $(2.461 \mathrm{~J} / \mathrm{mL})$ and heat treatment $\left(72{ }^{\circ} \mathrm{C}, 71 \mathrm{~s}\right.$ ), the $E$. coli $\mathrm{K} 12$ population in LMJ blend was reduced by $>6 \log 10 \mathrm{CFU} / \mathrm{mL}$. Principal component analysis (PCA) and hierarchical cluster analyses (HCA) showed a clear discrimination among the physicochemical properties of the control and the UV-C and heat-treated LMJ blends during storage, suggesting that UV-C irradiation has a comparable effect on microbial stability at $4{ }^{\circ} \mathrm{C}$ and better quality preservation performance than heat treatment.

Industrial relevance: Melon juice has many beneficial health effects. It has high sugar content, $\mathrm{pH}$ (5.6-6.0) and a fairly short shelf life. Therefore, pasteurization is required. But the thermal pasteurization has some undesired effects on the juice quality. Consumer demands for high quality fruit juice with fresh-like characteristics has markedly expanded in recent years. In this study, an alternative lemon-melon juice (LMJ) blend formulation was developed, and pasteurized using both UV-C irradiation and mild heat treatment. The shelf life stability of pasteurized LMJ blends was assessed by means of principal component analysis and hierarchical cluster analysis. The shelf life of LMJ blends treated by both methods was increased from 2 days to 30 days. The multivariate data analysis was successfully applied as a tool for an overall evaluation of the shelf-life of the product. UV-C irradiation has a comparable effect on microbial stability at $4{ }^{\circ} \mathrm{C}$ and better quality preservation performance than heat treatment for obtaining both shelf-stable and fresh-like LMJ blends. This would be a major advantage in processing of nutritious juice products.
\end{abstract}

(c) 2015 Elsevier Ltd. All rights reserved.

\section{Introduction}

Melon (Cucumis melo L.) is a fruit that has different cultivars, such as cantaloupe, muskmelon, honeydew and galia (Stepansky, Kovalski, \& Perl-Treves, 1999). It is rich in antioxidant and phenolic matter (Kenny, Smyth, Hewage, \& Brunton, 2013), as well as vitamin C content (Lester, 1997). Melon juice is a great thirst quencher, and it helps to ease inflammations and other symptoms caused by a variety of diseases such as diabetes, asthma, arthritis, colon cancer, and atherosclerosis (Lester, 1997).

Melon juice has a high sugar content and $\mathrm{pH}$ (5.6-6.0), which makes it a suitable medium for the growth of pathogenic and spoilage microorganisms; therefore, pasteurization is required to kill

\footnotetext{
* Corresponding author at: Department of Food Engineering, Engineering Faculty, Izmir Institute of Technology, 35430 Urla, Izmir, Turkey. Tel.: +90232 750 6317; fax: + 90232 7506196.

E-mail address: sevcanunluturk@iyte.edu.tr (S. Ünlütürk).
}

harmful bacteria (Gabriel \& Nakano, 2009). Food processing is becoming more sophisticated in order to meet today's consumers' expectations regarding fresh-like foods with high quality (Rastogi, Raghavarao, Balasubramaniam, Niranjan, \& Knorr, 2007; Sánchez-Moreno, De Ancos, Plaza, Elez-Martínez, \& Cano, 2009). Undesired effects of thermal processes, such as loss of nutrients, degradation of bioactive compounds, and changes in sensorial attributes, lead scientists to explore innovative food processing technologies with minimal heat treatment.

Ultraviolet (UV) irradiation is one of the non-thermal processes used for food materials (Caminiti et al., 2012; Keyser, Müller, Cilliers, Nel, \& Gouws, 2008; Koutchma, Forney, \& Moraru, 2010). UV-C light in the range of 200 to $280 \mathrm{~nm}$ has a germicidal effect on microorganisms including bacteria, yeast, molds, and viruses (Koutchma et al., 2010). UV-C irradiation approved by the FDA (FDA, 2000) has been successfully applied to pasteurize different types of liquid products, including orange juice (Tran \& Farid, 2004), apple juice (Caminiti et al., 2012), guava-and-pineapple juice, mango nectar, strawberry nectar (Keyser et al., 2008) pomegranate juice (Pala \& Toklucu, 2011), grape juice and wine (Fredericks, Du Toit, \& Krügel, 2011). 
Despite the growing interest, studies related to the preservation of melon and melon products by non-thermal processes are limited. Manzocco, Da Pieve, and Maifreni (2011) have been successfully applied UV-C light on fresh-cut melon as a novel technology for surface disinfection. In addition, dense-phase carbon dioxide pasteurization has been studied to evaluate the changes in physicochemical properties and flavor compounds (Chen et al., 2009) and has been used to inactivate the microorganisms and enzymes (Chen et al., 2010) in Hami melon juice. Ferrario, Alzamora, and Guerrero (2013) investigated the high-intensity light pulses for inactivation of Escherichia coli, Listeria innocua, Salmonella enteritidis and Saccharomyces cerevisiae in melon juice. Pulsed electric fields (Mosqueda-Melgar, Raybaudi-Massilia, \& Martín-Belloso, 2007) and high-intensity pulsed fields in combination with natural antimicrobials (Mosqueda-Melgar, Raybaudi-Massilia, \& Martín-Belloso, 2008) have been used to extend the shelf life of melon and watermelon juices. Nonetheless, the influence of non-thermal technologies on melon products still needs to be investigated in terms of microbial and quality attributes of the product.

The present study aimed (i) to evaluate the effect of UV-C irradiation and heat treatment on E. coli K12 (ATCC 25253) in a newly formulated lemon-melon juice (LMJ) blend; and (ii) to assess the changes in the physicochemical properties of control (untreated), UV-C-irradiated and heat-treated LMJ blends immediately after processing and one month of refrigerated storage by means of multivariate data analysis.

\section{Materials and methods}

\subsection{Materials}

Kirkagac (C. melo var. inodorus) and Galia (C. melo var. reticulatus) types of melon varieties and lemon (citrus $\times$ limon) were used for the formulation of the juice blend. Melon and lemon fruits were obtained at their commercial maturity from a local market in Izmir, Turkey.

\subsection{Fruit juice formulation and sensory evaluation}

Melons were washed under tap water, cut in half and sliced into long pieces, removing the seeds and peel. Slices of melons were squeezed by a juice extractor (Arçelik, Robolio, Istanbul, Turkey). Kırkagac and Galia melon juices were mixed in a ratio of 2 to $1(\mathrm{v} / \mathrm{v})$ in order to develop a melon juice mixture that is sweet and aromatic. The final $\mathrm{pH}$ of the juice blend was adjusted to $3.0,3.5$ and 4.0 by adding different amounts of lemon juice. Sensorial assessment was performed to determine the consumer acceptability of the formulated LMJ blend.

Sensory evaluation was carried out using 15 semi-trained panelists (Sallam, 2007). The panelists were graduate students and academic staff (nine female, six male) between the ages of 23 and 44 . They were familiar with the sensorial attributes of melon juice and acquainted with the scoring technique. An acceptance test was performed for three samples of fresh LMJ blends prepared at different $\mathrm{pH}$ values of 4.0, 3.5, and 3.0. The panelists were asked for their preferences in terms of particular attributes such as color, aroma, taste, appearance, and overall acceptance using a 5 -point structured hedonic scale. A score of 1 was the lowest and 5 was the highest score, indicating "extremely dislike" and "extremely like", respectively. The results of sensory evaluation were assessed using analysis of variance (ANOVA) and Tukey's pairwise comparison test $(\mathrm{p}<0.05)$. Internal consistency test was applied to calculate Cronbach's alpha (CA) coefficient using Minitab 16 (Minitab Inc., State College, PA, USA). CA measures the similarity between evaluation profiles from different panelists. An evaluation profile corresponds to assessments made by a panelist on a given attribute, over all products (Pinto, Fogliatto, \& Qannari, 2014).

\subsection{Microbiological studies}

\subsubsection{Bacterial strain and sample inoculation}

In this study, E. coli K12 (ATCC 25253), a surrogate of E. coli 0157:H7, was selected as a pertinent pathogen and inoculated into formulated LMJ blends. Koutchma, Keller, Chirtel, and Parisi (2004) found that UV sensitivities of E. coli 0157:H7 and a surrogate E. coli K12 (ATCC 25253 ) were not significantly different from each other. The E. coli K12 (ATCC 25253) strain was cultured from $-80^{\circ} \mathrm{C}$ lyophilized vials, enriched in a test tube containing nutrient broth (NB, Merck, Darmstadt, Germany) and incubated overnight (18-24 h) at $37^{\circ} \mathrm{C}$. The E. coli $\mathrm{K} 12$ (ATCC 25253 ) culture was first adapted to $\mathrm{pH} 4.0$ by growing in a solution containing tartaric acid following the procedure described by Pala and Toklucu (2013). Stock cultures were prepared by transferring acid-adapted cells onto TSA slants and stored at $4{ }^{\circ} \mathrm{C}$ until used.

Initially, LMJ blends were pasteurized by means of a water bath (Precisdig Model, JP Selecta S.A., Barcelona) to eliminate any background microflora prior to UV-C treatment. A loopful of acid-adapted culture from the TSA slant was first inoculated into $10 \mathrm{~mL}$ of TSB (TSB, Merck, Darmstadt, Germany) for enrichment, and then $1 \mathrm{~mL}$ from this culture medium was inoculated into $500 \mathrm{~mL}$ of LMJ blend ( $\mathrm{pH} \mathrm{4.0)}$ ) to obtain a final microbial concentration of 6-7 $\log \mathrm{CFU} / \mathrm{mL}$.

\subsubsection{UV-C treatment}

The inoculated LMJ blends were treated using a continuous-flow annular UV reactor. The schematic diagram of an S-shaped UV-C pasteurization system is shown in Fig. 1a. The UV system was made of a glass storage tank equipped with a cooling jacket, a pump (Watson Marlow Inc., England), an annular quartz glass tube surrounded by a cylindrical aluminum reflector (Afe Olgunlar Inc., Turkey) and seven UV-C lamps (254 nm, $15 \mathrm{~W}$ total output, UVP XX-15, UVP Inc., CA, USA). One of the UV lamps was located in the middle of the quartz tube, and the other UV lamps were assembled around the quartz tube (Fig. 1b). The gap size for annular flow was $5 \mathrm{~mm}$. Five hundred milliliters of LMJ blends was passed through the system by circulating cold water at $4{ }^{\circ} \mathrm{C}$ around the glass sample tank. The water around the glass tank was circulated by means of a water bath (Haake DL30, Thermo Electron Corp., Karlsruhe, Germany) equipped with a cooler (Haake EK45, Thermo Electron Corp., Karlsruhe, Germany). The temperature of juice at the outlet of the UV system and inside the sample tank was checked by a K-type thermocouple (CEM DT-8891E, Shenzhen, China), and measured as $16.53 \pm 1.35^{\circ} \mathrm{C}$ and $12.06 \pm 0.94{ }^{\circ} \mathrm{C}$, respectively. UV-C treatment resulted in $4.23 \pm 1.51{ }^{\circ} \mathrm{C}$ increase in the temperature of LMJ blends. UV treatments were carried out at two flow rates $(3.80 \mathrm{~mL} / \mathrm{s}$, $7.55 \mathrm{~mL} / \mathrm{s}$ ). The inoculated LMJ juice blends were circulated five or eight times through the reactor using four different lamp configurations including I (four lamps on), II (three lamps on), III (one lamp on) and IV (seven lamps on) (Fig. 1b). The total processing time for one pass was recorded manually for each flow rate by using a chronometer and determined as $124 \mathrm{~s}$ at $3.80 \mathrm{~mL} / \mathrm{s}$ and $70 \mathrm{~s}$ at $7.55 \mathrm{~mL} / \mathrm{s}$.

The applied UV dose was estimated by using a potassium iodide/ iodate actinometer (Rahn, 1997). The actinometer buffer was pumped through the UV-C system at each flow rate and lamp configuration. The increase in absorbance (352 nm) was measured at the outlet of the reactor. Thus, the photon flux (254 nm) received per volume unit was found and the corresponding effective dose was estimated.

The UV experiments were repeated three times for each flow rate, and sampling was performed after each cycle. The survival curve of microorganisms was drawn by plotting $\log \left(\mathrm{N} / \mathrm{N}_{0}\right)$ reductions versus time $(\mathrm{s})$, where $\mathrm{N}$ is the residual microbial load $(\mathrm{CFU} / \mathrm{mL})$ at a given time and $\mathrm{N}_{0}$ is the initial microbial load $(\mathrm{CFU} / \mathrm{mL})$.

\subsubsection{Heat treatment}

Initially, the thermal inactivation kinetic parameters ( $D$ and $z$ values) of E. coli $\mathrm{K} 12$ in LMJ blend were determined from the thermal 
(a)
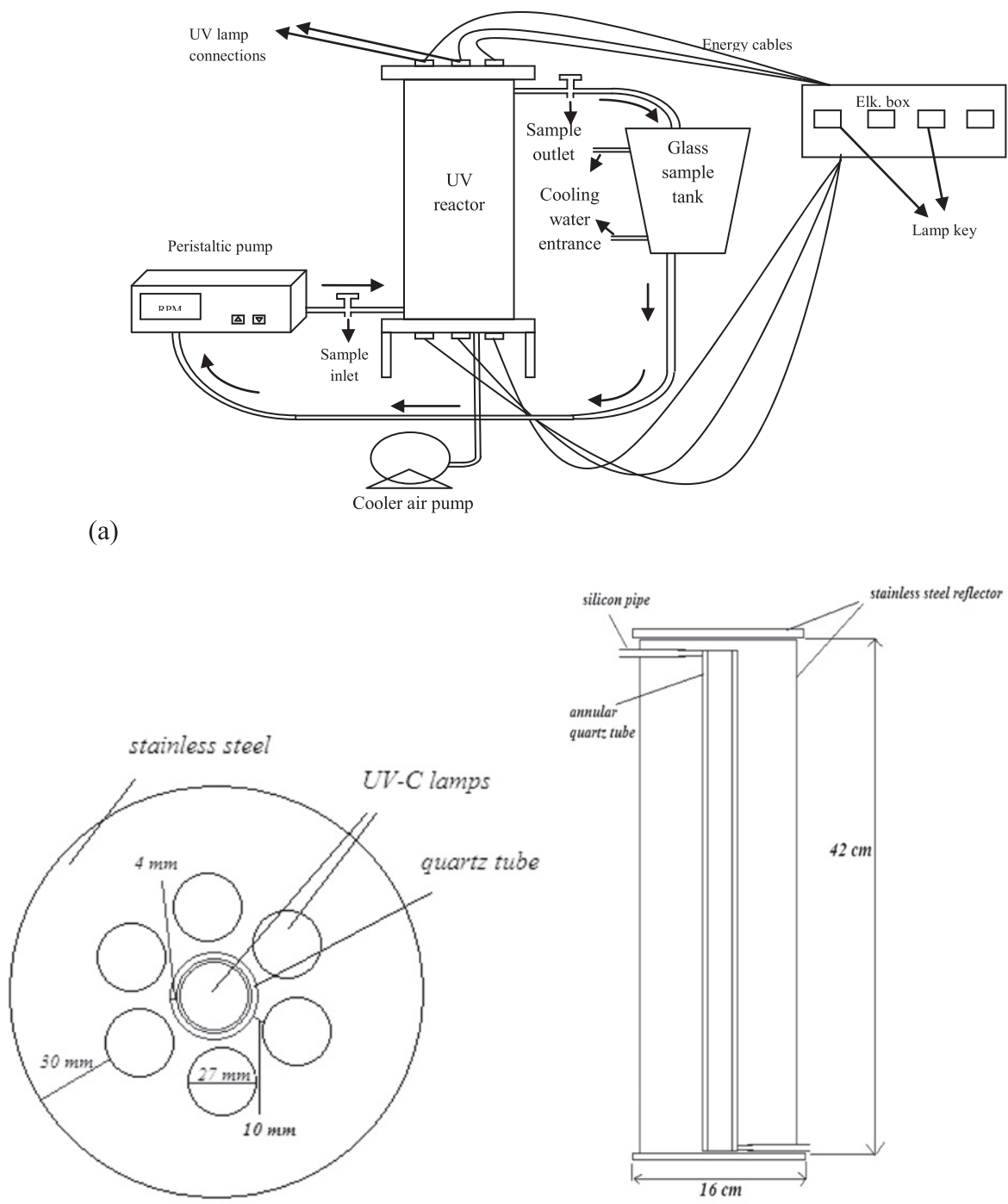

(b)

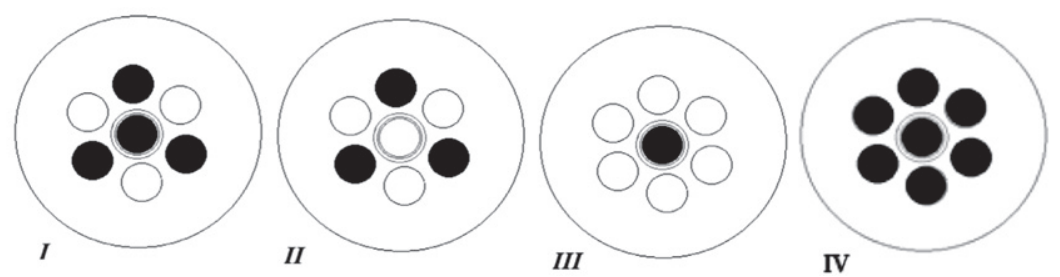

Fig. 1. (a) Schematic drawing of UV system. (b) Dimensions of the reactor and arrangements of 7 UV-C lamps (black circles: open lamps, empty circles: closed lamps).

death time curve. For this purpose, formulated juice blends were inoculated with $100 \mu \mathrm{l}$ of $E$. coli K12 cells. Heat treatments were carried out in a water bath (Precisdig Model, JP Selecta S.A., Barcelona) at different temperatures $\left(55,65,75,85^{\circ} \mathrm{C}\right)$ and different heating times $(0,1,2,5,10,120,240,480 \mathrm{~s})$. After inoculation, $0.1-\mathrm{mL}$ samples were collected at different heating times and immediately surface plated on tryptic soy agar (TSA, Merck, Darmstadt, Germany). $D$ values were initially determined, and subsequently, the $z$-value was found by plotting log D-values versus the temperature. After the determination of $\mathrm{D}$ and $\mathrm{z}$ values, the pasteurization temperature and time required for $5 \log$ reduction of E. coli K12 in LMJ blends were calculated.

\subsubsection{Bacterial enumeration}

To enumerate the viable microorganisms in the UV treated samples, appropriate dilutions were made with $0.1 \%$ peptone water and surface plated in duplicate on tryptic soy agar (TSA, Merck, Darmstadt, Germany) plates. All of the plates were incubated at $37{ }^{\circ} \mathrm{C}$ for $24 \mathrm{~h}$ and then counted. The untreated LMJ sample was used as a negative control, while a heat treated sample was used as a positive control in this study. Background flora (total aerobic bacteria (TAC), total coliform (TC), yeast and mold (YMC) counts) of the positive and negative control samples was checked by surface plating on tryptic soy agar (TSA, Merck, Darmstadt, Germany), violet red bile agar (VRBA, Merck, Darmstadt, Germany) and potato dextrose agar (PDA, Difco Laboratories, Detroit, 
Mich) acidified to pH 3.5 with 10\% tartaric acid (Merck, Darmstadt, Germany), respectively. The TSA and VRBA plates were incubated at $37^{\circ} \mathrm{C}$ for $24 \mathrm{~h}$, whereas the PDA plates were incubated at $25^{\circ} \mathrm{C}$ for $2-$ 5 days.

\subsection{Physicochemical properties of LMJ blends}

The total soluble solids (TSS), $\mathrm{pH}$, titratable acidity (TA), color, turbidity, and absorbance coefficients of treated and untreated LMJ blends were measured before and after UV-C and heat treatment. Soluble solid content ( ${ }^{\circ}$ brix) was measured at $20^{\circ} \mathrm{C}$ using a benchtop refractometer (Mettler-Toledo RE40D, AEA Investors Inc., USA), and the $\mathrm{pH}$ was determined using a benchtop pH meter (HANNA Instruments, USA). The titratable acidity of treated and untreated LMJ blends was determined according to the method of AOAC (1990) and expressed as the weight of citric acid in $100 \mathrm{~mL}(\mathrm{w} / \mathrm{v})$. The color of the LMJ blends was determined using a Konica Minolta CR 400 Chromometer (Konica Inc., Japan) in Hunter $\mathrm{L}^{*}$ (brightness-darkness), a* (redness-greenness), b* (yellowness-blueness) color space. Total color differences $(\Delta \mathrm{E})$ were calculated by the following Eq. (1).

$\Delta \mathrm{E}=\sqrt{\left.(\Delta \mathrm{L} *)^{2}+(\Delta \mathrm{a} *)^{2}+(\Delta \mathrm{b} *)^{2}\right)}$

The turbidity was measured using a turbidimeter (Model 2100AN IS, HACH Company, USA) and expressed in Nephelometric Turbidity Units (NTU). Absorbance coefficients for the LMJ blend samples were determined using a 1-cm quartz cuvette in a Cary 100 UV-Visible Spectrophotometer (Varian, USA) adjusted to $254 \mathrm{~nm}$. A variety of dilution factors were applied (1:10, 1:25, 1:50, 1:100, 1:250, 1:500). The absorption coefficient $\left(\mathrm{cm}^{-1}\right)$ was estimated from the slope of the absorbance versus sample concentration plot.

\subsection{Storage study}

Untreated, UV-C-treated and heat-treated LMJ blends were stored at refrigerated conditions $\left(4.0 \pm 0.82{ }^{\circ} \mathrm{C}\right)$ for 30 days. UV-C-treated LMJ blends were circulated eight times at $3.80 \mathrm{~mL} / \mathrm{s}$ through the reactor using lamp configuration I (Fig. 1b). Heat-treated blends were pasteurized at $72{ }^{\circ} \mathrm{C}$ for $71 \mathrm{~s}$. The pasteurization conditions were calculated from the thermal inactivation kinetic parameters (in Section 3.3). Samples were taken at 3-6-day intervals for each analysis. Microbiological analysis (total aerobic bacteria, total coliforms, yeasts and molds) and physicochemical properties ( $\mathrm{pH}$, brix, titratable acidity, absorbance, turbidity, color) were measured during the storage period.

\subsection{Data analysis}

Statistical analyses, t-tests and ANOVA tests were carried out using the Minitab 16 (Minitab Inc., State College, PA, USA), and differences were considered to be significant for $\mathrm{p} \leq 0.05$. Regression analysis was performed for the thermal kinetic parameters ( $D$ and $\mathrm{z}$ ) and UV inactivation data by using a commercial spread sheet (Microsoft Excel, Redmond, WA, USA). All the experiments and following assays were replicated at least three times.

Multivariate statistical analyses including principal component analysis (PCA) and hierarchical cluster analysis (HCA) were conducted to visualize the data structure of untreated, UV-C-irradiated, and heattreated LMJ blends. PCA is a widely used multivariate analysis technique based on the transformation of original measurement variables into new variables called principal components (PC). Each principal component is a linear combination of the original measurement variables (Banas et al., 2010). A data matrix was constructed using the analyzed physicochemical properties in columns and the days during shelf life in rows. A correlation type of matrix and eight components were computed. Score and loading plots were drawn as the PCA output using SIMCA 13.0.3 statistical software (Umetrics Inc., San Jose, CA, USA).

HCA is an unsupervised clustering method that is constructed considering the similarity or differences among observations (Huang, Guo, Qiu, \& Chen, 2007). The use of standardized data allows for the ability to assign a standard numerical weight to each variable, which have different magnitudes and ranges of variation (Versari, Parpinello, \& Galassi, 2002). Because variables with large variances tend to have a larger effect on the resulting clusters compared to variables with small variances, the PC-scores were loaded as new input data for clustering study. HCA characterizes the samples based on the evaluation of the similarity between the samples by measuring the distances between the points in the measurement space. Dissimilar samples will be distant from each other, while the samples that are similar will lie close to one another. Clustering analysis was computed in consideration of Ward's linkage as an amalgamation method and Euclidean distance as a similarity measurement. HCA resulted in the similarity of observations given as a dendrogram, which is defined as a tree-shaped map of the inter sample distances in the data set by Banas et al., 2010.

\section{Results and discussion}

\subsection{Sensory evaluation of formulated LMJ blends}

Lemon melon juice (LMJ) blend formulation was developed based on the sensorial assessment of three different blend compositions with varying $\mathrm{pH}$ values (3.0, 3.5, and 4.0). The average of sensory acceptance scores of blends varied from $2.81 \pm 1.29$ ("neither liked nor disliked") to $3.65 \pm 0.99$ ("liked"). The color, aroma, taste, appearance, and overall quality attributes of different blends with varying $\mathrm{pH}$ values of 3.0, 3.5 and 4.0 are shown in the radar plot in Fig. 2. While three types of blends had a similar acceptance in terms of color and appearance, the blend with pH 4.0 was chosen to be most favorable. Indeed, statistical evaluation of sensorial analysis (Fig. 2) suggested that there was not a significant difference between the blends with $\mathrm{pH}$ value of 4.0 and 3.5.

According to Mitchell and Jolley (1996), alpha coefficient values larger than 0.70 are considered acceptable, indicating panelists presenting similar evaluation profiles. Flynn, Sakakibara, Schroeder, Bates, and Flynn (1990) stated that, alpha coefficient values equal to 0.60 or larger are deemed acceptable for panelists unfamiliar with the scale. Since CA coefficient based on the internal consistency test was calculated as 0.704, panel results are considered satisfactory. Therefore, an acceptable $\mathrm{pH}$ value of the juice blend was considered to be between $\mathrm{pH} 3.5$ and

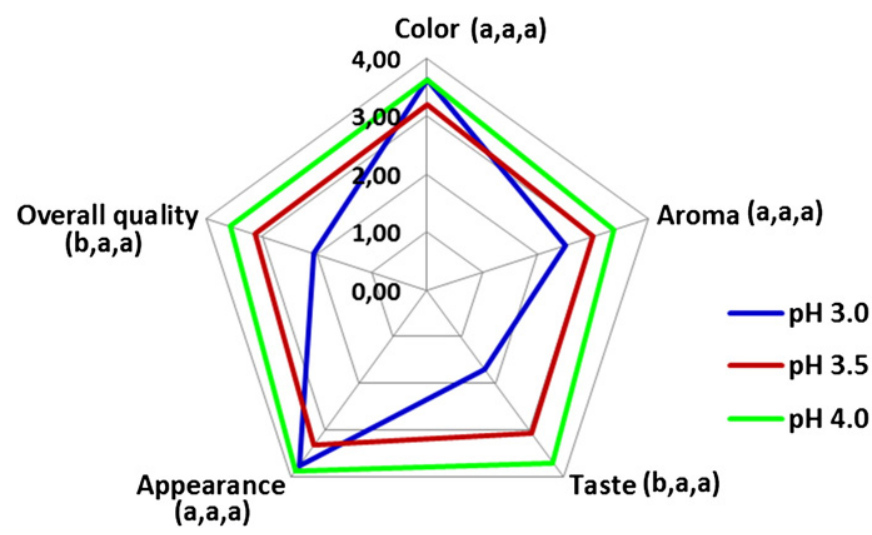

Fig. 2. Sensorial assessment of newly formulated LMJ blends. The different small-case letters in parenthesis indicate the significant differences among LMJ blend at $\mathrm{pH} 3.0,3.5$, and 4.0 based on Tukey pairwise comparison test $(\mathrm{p}<0.05)$. 
4.0 , and subsequently, the final $\mathrm{pH}$ was adjusted to $3.92 \pm 0.01$ by introducing $12 \%(\mathrm{v} / \mathrm{v})$ lemon juice into the melon juice. This formula of the blend was used throughout the study.

\section{2 . Inactivation of E. coli K12 with UV-C irradiation}

The inactivation performance of UV-C irradiation on E. coli K12 was evaluated by using two volumetric flow rates (3.80 and $7.55 \mathrm{~mL} / \mathrm{s}$ ) and four lamp configurations (I, II, III, IV). All samples were circulated five or eight times in the UV system. It was found that the higher flow rate $(7.55 \mathrm{~mL} / \mathrm{s})$ resulted in the lower microbial reductions (Table 1 ). This was likely due to the lower residence time that was coupled with the higher flow rate. Accordingly, design I (four lamps on) resulted in $3.40 \pm 0.01 \log _{10} \mathrm{CFU} / \mathrm{mL}$ reductions in the $E$. coli $\mathrm{K} 12$ count when the LMJ blend was circulated five times at $3.80 \mathrm{~mL} / \mathrm{s}$ in the UV system, which led to a reduction of $1.93 \pm 0.01 \mathrm{CFU} / \mathrm{mL}$ at $7.55 \mathrm{~mL} / \mathrm{s}$. The cycling time was also found to be an important factor for the inactivation efficiency of the system.

The estimated UV dose level ranged from $0.444 \mathrm{~J} / \mathrm{mL}$ to $2.855 \mathrm{~J} / \mathrm{mL}$ depending on the lamp configuration and cycling time (Table 1 ). As seen in Table 1, a $3.40 \pm 0.01 \log _{10} \mathrm{CFU} / \mathrm{mL}$ reduction was achieved after UV-C treatment at a dose of $1.51 \mathrm{~J} / \mathrm{mL}$ (five passes), while $E$. coli K12 was reduced by $6.19 \log _{10} \mathrm{CFU} / \mathrm{mL}$ after a UV-C dose of $2.461 \mathrm{~J} / \mathrm{mL}$ (eight passes) when lamp configuration I was employed. In the case of lamp configuration IV, $5.70 \pm 0.63 \log _{10} \mathrm{CFU} / \mathrm{mL}$ reduction in E. coli $\mathrm{K} 12$ was obtained when the LMJ blend was subjected to a UV dose of $2.855 \mathrm{~J} / \mathrm{mL}$ (eight passes), suggesting that higher levels of UV irradiation did not improve the inactivation performance of the UV system. Additionally, the color of the samples was adversely affected when all of the UV-C lamps were turned on (IV) (data not shown).

Franz, Specht, Cho, Graef, and Stahl (2009) studied naturally cloudy apple juice with different flow rates and found that a flow rate of $4 \mathrm{~L} / \mathrm{h}$ with residence time of $21 \mathrm{~s}$ reduced the number of $E$. coli DH5 $\alpha$ from the initial microbial load of $10^{6} \mathrm{CFU} / \mathrm{mL}$ to $10^{1}-10^{2} \mathrm{CFU} / \mathrm{mL}$, while a flow rate of $2 \mathrm{~L} / \mathrm{h}$, corresponding a 41 -s residence time, provided complete inactivation of $E$. coli cells. So, this finding is line with our study concluding that the lower flow rate $(3.80 \mathrm{~mL} / \mathrm{s})$ was resulted in the highest microbial inactivation (6.19 $\left.\log _{10} \mathrm{CFU} / \mathrm{mL}\right)$. Moreover, Gayan, Serrano, Monfort, Álvarez, and Condón (2012) reported $0.64 \pm 0.04$ log reduction of $E$. coli STCC 4201 in orange juice treated with $27.10 \mathrm{~J} / \mathrm{mL}$ of UV irradiation at a constant flow rate of $8.5 \mathrm{~L} / \mathrm{h}$ in the annular thin-film UV system. They achieved only a $0.25 \pm 0.04 \log$ reduction of $E$. coli after UV-C treatment with a UV dose of $13.55 \mathrm{~J} / \mathrm{ml}$ at the same flow rate. Likely, Pala and Toklucu (2013) achieved $5.72 \log$ reduction of E. coli ATTC 25922 in orange juice treated with a UV dose of $36.09 \mathrm{~kJ} / \mathrm{L}$ (three passes), while E. coli ATTC 25922 was completely inactivated after a UV dose of $60.15 \mathrm{~kJ} / \mathrm{L}$ (five passes).

In this study, UV-C treatment carried out at the processing conditions where the juice blends circulated eight times with a total processing time of $980 \mathrm{~s}$ at a flow rate of $3.80 \mathrm{~mL} / \mathrm{s}$ and UV dose of $2.461 \mathrm{~J} / \mathrm{mL}$ using configuration (I) was resulted in $6.19 \log _{10} \mathrm{CFU} / \mathrm{mL}$ reduction of E. coli $\mathrm{K} 12$ in LMJ blends.

\section{Table 1}

Inactivation of $E$. coli $\mathrm{K} 12$ in the blend of LMJ treated by UV-C irradiation using different processing conditions.

\begin{tabular}{lllll}
\hline Cycle & $\begin{array}{l}\text { Volumetric flow } \\
\text { rate }(\mathrm{mL} / \mathrm{s})\end{array}$ & UV Dose $(\mathrm{J} / \mathrm{mL})^{\mathrm{a}}$ & $\begin{array}{l}\text { Lamp } \\
\text { configuration }\end{array}$ & $\begin{array}{l}\text { Log reduction } \\
\log \left(\mathrm{N} / \mathrm{N}_{0}\right)\end{array}$ \\
\hline 5 & 3.80 & $1.510 \pm 0.002$ & I & $3.40 \pm 0.01$ \\
& & $0.841 \pm 0.001$ & II & $0.83 \pm 0.06$ \\
& \multirow{2}{*}{7.55} & $0.757 \pm 0.0004$ & III & $1.20 \pm 0.16$ \\
& & $0.968 \pm 0.0004$ & I & $1.93 \pm 0.01$ \\
& \multirow{2}{*}{3.80} & $0.549 \pm 0.001$ & II & $0.86 \pm 0.19$ \\
& & $2.444 \pm 0.0002$ & III & $0.06 \pm 0.05$ \\
& $2.461 \pm 0.002$ & I & $6.19 \pm 0.16$ \\
\hline
\end{tabular}

\footnotetext{
a Estimated from potassium iodide/iodate actinometric method.
}

\subsection{Inactivation of E. coli K12 with heat treatment}

The calculated D values of $E$. coli $\mathrm{K} 12$ strains at $55,65,75$, and $85{ }^{\circ} \mathrm{C}$ were $298.57 \pm 6.30,128.23 \pm 2.32,5.30 \pm 0.06,0.99 \pm 0.02 \mathrm{~s}$, respectively. Gabriel (2012) calculated a D value of $4.43 \mathrm{~min}(283 \mathrm{~s})$ for E. coli 0157: $\mathrm{H7}$ (HCIPH-96055) in the apple juice heated to $55^{\circ} \mathrm{C}$. This result is slightly lower than our findings, which is likely the result of using different $E$. coli strains. In another study performed by Gabriel and Nakano (2009), E. coli K12 was used as a test bacterium in the clear apple juice heated to $55{ }^{\circ} \mathrm{C}$. The D value for $E$. coli $\mathrm{K} 12$ was reported to be $0.96 \mathrm{~min}$, which is lower than our results. Gabriel and Nakano (2009) indicated that their test microorganism in the apple juice medium was not acid-adapted. Therefore, E. coli K12 may be damaged by the acidity of the apple juice subsequent to inoculation. The $\mathrm{z}$ value of $E$. coli $\mathrm{K} 12$ in the LMJ blend was $11.33 \pm 0.01{ }^{\circ} \mathrm{C}$. This value was slightly higher than the value at $7.5^{\circ} \mathrm{C}$ reported by CCFRA (1992) for target microorganisms in high-acid products, including fruit juices. The higher $\mathrm{D}$ and $z$ values obtained in our study may be the result of using an acidadapted $E$. coli strain, which is expected to be more resistant to low pH conditions.

Mazzotta (2001) indicated that industrial pasteurization conditions for the fruit juices are $90{ }^{\circ} \mathrm{C}$ and $2 \mathrm{~s}$ or $84{ }^{\circ} \mathrm{C}$ and $20 \mathrm{~s}$. However, these temperatures often result in losses of nutritional value and quality. Therefore, mild heat pasteurization over the range of 70 to $72{ }^{\circ} \mathrm{C}$ have begun to be applied in many studies to ensure high quality in several types of fruit juices (Timmermans et al., 2011). The FDA has also recommended a minimum temperature $\left(71.1^{\circ} \mathrm{C}\right)$ and time $(3 \mathrm{~s})$ for pasteurization of food products over the $\mathrm{pH}$ range of 3.6 and 4.0 (FDA, 2004).

In conclusion, a mild heat treatment at $72{ }^{\circ} \mathrm{C}$ for $71 \mathrm{~s}$ was adequate to reduce the $E$. coli $\mathrm{K} 12$ population in $\mathrm{LMJ}$ blends by $>5 \log \mathrm{CFU} / \mathrm{mL}$.

\subsection{UV-C irradiation and heat treatment of control samples}

Initially, the untreated (control) LMJ blend sample had $2.86 \pm$ $0.10 \log$ CFU/mL of TAC, $2.22 \pm 0.16 \log$ CFU/mL of YMC, and $2.21 \pm$ $0.14 \log \mathrm{CFU} / \mathrm{mL}$ of TC counts. UV-C irradiation (3.80 mL/s, lamp configuration I, eight cycles, $2.461 \mathrm{~J} / \mathrm{mL}$ of applied UV-C dose) was able to eliminate the entire background microflora of untreated juice samples (Fig. 3). Pala and Toklucu (2013) reported that a UV dose of $36.09 \mathrm{~J} / \mathrm{mL}$ was sufficient to reduce the total aerobic, yeast and mold load of orange juice by $2.8 \mathrm{log}$ and $0.34 \mathrm{log}$, respectively. They indicated that a UV-C dose of $36.09 \mathrm{~J} / \mathrm{mL}$ was not sufficient for the complete elimination of yeast and molds in orange juice. Guevara, Tapia, and Gómez-López (2012) achieved only a $0.5 \log$ reduction of aerobic mesophylls, yeasts

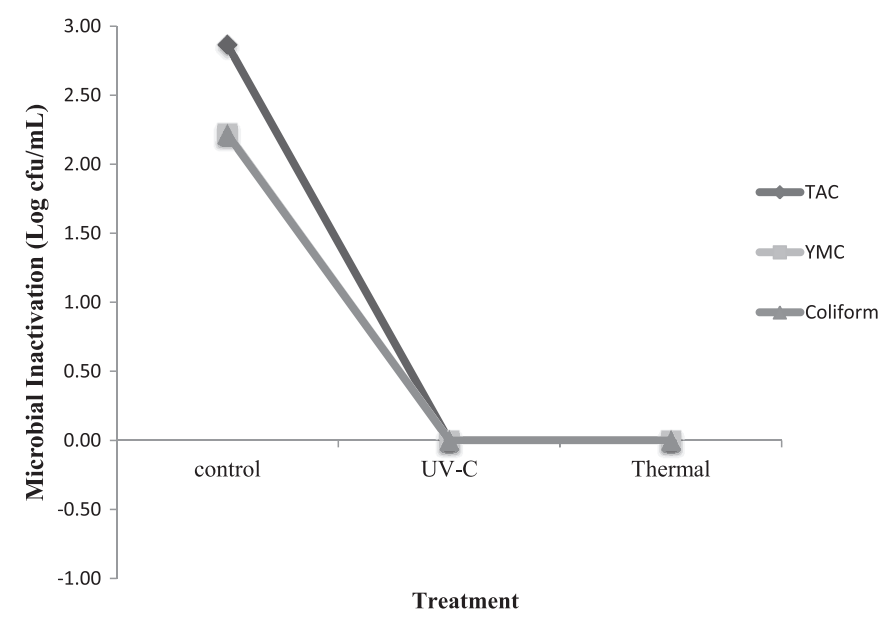

Fig. 3. Inactivation of initial microflora by UV-C treatment and thermal pasteurization. (TAC: total aerobic count, YMC: yeast mold count, and coliform). 
and molds in guava nectar treated with a UV dose of $23.62 \mathrm{~J} / \mathrm{mL}$. However, Tran and Farid (2004) observed $3.68 \log$ and 3.55 log reductions in total aerobic count and yeasts and mold count, respectively, in reconstituted orange juice treated with a $73.8 \mathrm{mWs} / \mathrm{cm}^{2}$ (calculated as $3.6 \mathrm{~J} / \mathrm{mL}$ based on their processing conditions). Viable cells were not recovered in LMJ juice blends after the heat treatment applied at $72{ }^{\circ} \mathrm{C}$ for $71 \mathrm{~s}$. Similarly, Timmermans et al. (2011) successfully applied mild heat pasteurization (72 ${ }^{\circ} \mathrm{C}$ and $20 \mathrm{~s}$ ) to orange juice samples. Walkling-Ribeiro, Noci, Cronin, Lyng, and Morgan (2010) pasteurized a fruit smoothie-type beverage at $72{ }^{\circ} \mathrm{C}$ for $15 \mathrm{~s}$. The TAC and YMC load of the beverage were reduced by $3.5 \log$ and $3.7 \log$ after mild heat treatment. Moreover, Vegara, Martí, Mena, Saura, and Valero (2013) observed a 4.59 log reduction of the aerobic plate count in the cloudy pomegranate juice after heat treatment applied at $65^{\circ} \mathrm{C}$ for $30 \mathrm{~s}$.

\subsection{Effect of UV-C and heat treatment on the physicochemical properties of LMJ blends}

Changes in the physicochemical properties of LMJ blends before and after UV-C $(2.461 \mathrm{~J} / \mathrm{mL})$ and heat treatments $\left(72{ }^{\circ} \mathrm{C}, 71 \mathrm{~s}\right)$ are provided in Table 2. There were no significant differences between untreated (control), UV-C-treated and heat-treated LMJ blends in terms of $\mathrm{pH}$ (3.92-3.93) and titratable acidity $(0.48-0.51 \%)(\mathrm{p}<0.05)$. Our results were in agreement with other studies reporting no significant changes in $\mathrm{pH}$ and titratable acidity of different types of fruit juices treated with UV-C light and heat treatment (Caminiti et al., 2012; Falguera, Pagan, \& Ibarz, 2011; Noci et al., 2008; Pala \& Toklucu, 2011, 2013).

The turbidity increased regardless of the sample treatments. However, the change in turbidity in the heat-treated samples was more pronounced in comparison to those of the irradiated and control samples. Similarly, Rivas, Rodrigoa, Martíneza, Barbosa-Cánovas, and Rodrigo (2006) observed an increase in the turbidity of the blended orange and carrot juice after thermal treatment. Heat treatment causes the degradation of pectin in cloud which may enable the proteins in cloud to combine with polyphenols and precipitate. Protein-polyphenol interaction causes an increase in turbidity. Additionally, the coagulation of degraded pectin combined with other components then resulted in an increase in turbidity and cloud content (Yen \& Lin, 2006). Another possible reason may be the result of inefficient pectin methyl esterase (PME) enzyme inactivation in LMJ blends. Various studies have shown that UV-C irradiation is unable to inactivate PME enzyme in fruit juices. For example, Tran and Farid (2004) reported that UV-C treatment was able to inactivate only 5\% of PME enzyme and did not prevent the cloudiness of the orange juice after UV treatment ( $73.8 \mathrm{~mJ} / \mathrm{cm} 2 \mathrm{UV}$ dose). Moreover, Zhang et al. (2011) observed 35\% residual PME activity in watermelon juice subjected to a UV dose of $9.7 \mathrm{~J} / \mathrm{mL}$. Sew, Ghazali, Martín-Belloso, and Noranizan (2014) also reported that PME enzyme could not be inactivated in pineapple juice exposed to UV-C irradiation $\left(11.23 \mathrm{~mJ} / \mathrm{cm}^{2} \mathrm{UV}\right.$ dose). Commercial heat pasteurization for the production of shelf-stable juices is designed to inactivate PME, which is more heat resistant than vegetative microorganisms. In this study, mild heat treatment conditions were chosen to producing high-quality LMJ blends for refrigerated storage. Therefore, it is speculated that none of the treatments was able to inactivate PME completely. In fact,
Vervoort et al. (2012) reported that mild heat pasteurization $\left(72{ }^{\circ} \mathrm{C}\right.$, $20 \mathrm{~s}$ ) of orange juice resulted in a PME activity decrease of $85 \%$, which supports the previous statement.

The absorption coefficient of the UV-C-treated sample $\left(11.12 \mathrm{~cm}^{-1}\right)$ was lower than that of the control $\left(14.88 \mathrm{~cm}^{-1}\right)$ and heat-treated samples $\left(14.94 \mathrm{~cm}^{-1}\right.$ ) (Table 2). Although the ascorbic acid content of the samples was not measured in this study, Koutchma (2008) reported that the degradation of vitamin $\mathrm{C}$ was the reason for the decrease in the absorption coefficient of fruit juices.

The total soluble solid content ( ${ }^{\circ}$ brix) of LMJ blends decreased slightly after UV-C and heat treatments. Similarly, Pala and Toklucu (2011) also reported a decrease in the total soluble solids for UV-C treated pomegranate juice.

The color parameter of a* value (redness-greenness) was not changed in all treatments (Table 2 ). Similarly, the $\mathrm{L}^{*}$ value (brightness-darkness) of the LMJ blend juice was not significantly affected by the UV-C treatment, whereas it was slightly increased by heating. The $b^{*}$ value (yellowness-blueness) of the juice samples was significantly reduced after treatment $(p<0.05)$. This could be explained by degradation of carotenoid pigments, which is often observed to a large extent in the melon fruit (Fratianni, Cinquanta, \& Panfili, 2010). Similarly, Ibarz, Pagán, Panadés, and Garza (2005) and Bhat, Ameran, Voon, Karim, and Tze (2011) indicated that bleaching of juices can be a result of phytochemical destruction of polymeric compounds by UV-C irradiation. Sánchez-Moreno et al. (2009) also reported a higher $\mathrm{L}^{*}$ value in orange juice after mild heat pasteurization at $72{ }^{\circ} \mathrm{C}$. The total color difference $(\Delta \mathrm{E})$ of the LMJ blend samples varied slightly after the treatments (Table 2). $\Delta \mathrm{E}$ values were classified as slightly noticeable (between 0.5 and 1.5) according to Cserhalmi, Sass-Kiss, Tóth-Markus, and Lechner (2006). However, the $\Delta \mathrm{E}$ value of UV-C treated samples $(0.63 \pm 0.05)$ was smaller than those of the heat treated samples $(0.90 \pm 0.02)$. Noci et al. (2008) also found less variation in the color of UV-C-treated apple juice $(\Delta \mathrm{E}, 0.55)$ compare to heat-treated samples $(\Delta \mathrm{E}, 1.86)$.

\subsection{Microbial shelf life of LMJ blends}

Logarithmic changes in total aerobic bacteria (TAC), yeast and mold (YMC), and total coliform (TC) counts of untreated (control), UV-Ctreated and heat-treated LMJ blends during 30 days of refrigerated storage $\left(4.0 \pm 0.82{ }^{\circ} \mathrm{C}\right)$ were evaluated. Initially, untreated LMJ blends had $2.86 \pm 0.04 \log \mathrm{CFU} / \mathrm{mL}$ of TAC, $2.22 \pm 0.07 \log \mathrm{CFU} / \mathrm{mL}$ of YMC, and $2.21 \pm 0.17 \log \mathrm{CFU} / \mathrm{mL}$ of TC counts, respectively. The number of coliform bacteria permitted in fruit juices is a maximum $100 \mathrm{CFU} / \mathrm{mL}$ ( $2 \log$ CFU/mL) (Al-Jedah \& Robinson, 2002). The TC counts of untreated LMJ blends at the end of storage period ( 5 days) were found to be $1.85 \pm 0.13 \log \mathrm{CFU} / \mathrm{mL}$ which was below the allowed limit. Conversely, the TAB and YM counts of untreated (control) samples increased to $4.26 \pm 0.01 \log \mathrm{CFU} / \mathrm{mL}$ and $4.39 \pm 0.02 \log \mathrm{CFU} / \mathrm{mL}$ within the first 2 days. According to the microbial criteria mandated by Turkish Food Codex, Microbiological Criteria, No: 2001/19, the acceptable maximum TAC and YMC counts in fruit juice and nectars must be 4 and 3 log $\mathrm{CFU} / \mathrm{mL}$, respectively (Turkish Food Codex, 2002). Therefore, juice having TAB and YM counts higher than these values is spoiled and cannot be sold in the market. UV-C-irradiated and heat-treated LMJ blends

Table 2

Physicochemical properties of untreated, UV-C treated $(2.46 \mathrm{~J} / \mathrm{mL})$ and heat treated $\left(72{ }^{\circ} \mathrm{C}, 71 \mathrm{~s}\right) \mathrm{LMJ}$ blends.

\begin{tabular}{|c|c|c|c|c|c|c|c|c|c|}
\hline \multirow[t]{2}{*}{ Treatment } & \multirow[t]{2}{*}{$\mathrm{pH}$} & \multirow{2}{*}{$\begin{array}{l}\text { Soluble solid } \\
\text { ( }{ }^{\circ} \text { brix) }\end{array}$} & \multirow[t]{2}{*}{$\mathrm{TA}(\%)$} & \multirow{2}{*}{$\begin{array}{l}\text { Absorption coefficient } \\
\left(\mathrm{cm}^{-1}\right)\end{array}$} & \multirow{2}{*}{$\begin{array}{l}\text { Turbidity } \\
\text { (NTU) }\end{array}$} & \multicolumn{4}{|l|}{ Color } \\
\hline & & & & & & $\mathrm{L}^{*}$ & $a^{*}$ & $b^{*}$ & $\Delta \mathrm{E}$ \\
\hline Control (untreated) & $3.93 \pm 0.01 a$ & $8.72 \pm 0.11 \mathrm{a}$ & $0.51 \pm 0.01 \mathrm{a}$ & $14.88 \pm 0.04 a$ & $278.50 \pm 2.38 c$ & $27.69 \pm 0.02 a$ & $0.06 \pm 0.01 \mathrm{a}$ & $2.48 \pm 0.02 \mathrm{a}$ & oc \\
\hline UV-C & $3.93 \pm 0.01 a$ & $8.51 \pm 0.05 b$ & $0.50 \pm 0.00 \mathrm{a}$ & $11.12 \pm 0.02 b$ & $292.75 \pm 0.96 b$ & $27.84 \pm 0.14 a$ & $0.11 \pm 0.06 a$ & $1.88 \pm 0.03 b$ & $0.63 \pm 0.05 b$ \\
\hline Heat & $3.92 \pm 0.01 a$ & $8.55 \pm 0.02 b$ & $0.48 \pm 0.05 a$ & $14.94 \pm 0.22 \mathrm{a}$ & $342.50 \pm 0.71 a$ & $28.07 \pm 0.01 b$ & $0.07 \pm 0.02 \mathrm{a}$ & $1.66 \pm 0.02 c$ & $0.90 \pm 0.02 a$ \\
\hline
\end{tabular}

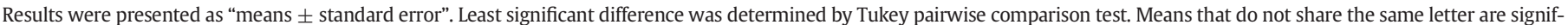
icantly different $(\mathrm{p}<0.05)$.

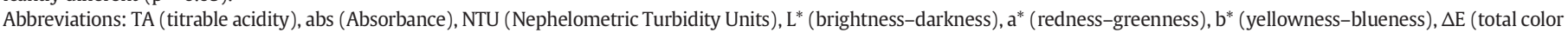
difference). 
exhibited no microbial growth during 30 days of refrigerated storage. Pala and Toklucu (2013) were able to extend the shelf life of UV-Cirradiated orange juice up to 9 days at $4{ }^{\circ} \mathrm{C}$ and 5 days at $10^{\circ} \mathrm{C}$. Similarly, Tran and Farid (2004) reported the shelf life of UV treated orange juice to be more than 5 days under refrigerated conditions. In conclusion, UVC treatment (2.461 J/mL UV dose) successfully extended the shelf life of LMJ blends by more than 30 days under the refrigerated conditions.

\subsection{Multivariate statistical analysis of physicochemical properties of LMJ blends during shelf life period}

The changes in the physicochemical and optical properties of LMJ blends during the storage period are shown in Table 3. Untreated (control) samples were analyzed after only 5 days, as the juice samples were spoiled at the end of this period. All of the physical properties of untreated samples changed significantly within 5 days of storage. Conversely, the $\mathrm{pH}$ and titratable acidity (TA) of the UV-C- and heat-treated LMJ blends were not changed significantly during 30 days of refrigerated storage. These findings were in accordance with the study published by Chisari, Barbagallo, Spagna, and Artes (2011), where changes in the $\mathrm{pH}$ and TA of fresh-cut UV-C-treated melon slices during 10 days of storage were not observed. However, the total soluble solids (TSS) of a UV-C- and heat-treated LMJ blend was significantly increased during the storage period $(\mathrm{p}<0.05)$.

During the first 16 days of storage, the absorption coefficient of UVC-treated samples did not exhibit any changes but decreased to $9.63 \pm$ $0.24 \mathrm{~cm}^{-1}$ afterwards. Conversely, the absorption coefficient of heattreated LMJ blends presented a statistically significant reduction within the first five days of the storage period.

The turbidity of untreated samples increased during the storage period. This was explained by the increase in the microbial growth of yeast and bacteria that has been shown to induce cloudiness and sedimentation in the juice (Canitez, 2002). The UV-C-irradiated blend had lower turbidity than the heat-treated samples throughout the storage period. The turbidity of the UV-C treated blends was not affected until the 16th day of storage when some fluctuation occurred until the end of 30 days of storage period. In contrast, the heat treated samples exhibited a significant increase in turbidity during the whole storage period $(p<0.05)$. Lee, Yusof, Hamid, and Baharin (2007) reported that the turbidity increment in the juice during storage could arise from the effect of protein and polyphenol complexes. The change in turbidity of the LMJ blend juice can also be related to the residual PME activity after the treatments (Rivas et al., 2006).

The $\mathrm{L}^{*}$ (brightness) value of UV-C-irradiated samples was slightly higher than that of the heat-treated LMJ blend. Similarly, Donahue, Canitez, and Bushway (2004) reported the brightening effect of UV-C light by observing an increase in the $\mathrm{L}^{*}$ value of UV-C-irradiated apple cider throughout a 3-week storage period. The $b^{*}$ (yellowness) value of the UV-C-treated LMJ blend generally showed an increasing trend throughout the storage period. However, no trend was observed for the $b^{*}$ values of the heat-treated samples. The $a^{*}$ (redness-greenness) values of UV-C- and heat-treated LMJ blends decreased significantly $(\mathrm{p}<0.05)$ throughout the storage period. Total color differences $(\Delta \mathrm{E})$ of the UV-C- and heat-treated LMJ samples were generally not noticeable (between 0-0.5) during 30 days of storage. Likewise, Cortes, Esteve, and Frígola (2008) also found an increase in the $\Delta \mathrm{E}$ of pasteurized and HIPEF-treated orange juice depending on the deterioration of color pigments during 7 weeks of storage.

The multivariate data analysis was able to clearly discriminate UV-Ctreated and heat-treated samples from control (untreated) samples based on their physicochemical properties measured during the storage period. PCA outputs obtained as the score and loading plots are given in Fig. 4. The data for heat-treated samples collected during 30 days of storage were remarkably distinguished from the others. The individual contribution of variances of PC1, PC2, PC3, PC4 and PC5 in each plot was found to be $29.99 \%, 21.11 \%, 17.36 \%, 11.78 \%$ and $8.12 \%$, respectively. Accordingly, the total cumulative variance of the first two components (51.09\%) was able to separate the data points of the treatments. Table 4 shows the loadings, eigenvalues, and percent of cumulative variances for the first five principal components. Although PC1, PC2, PC3, PC4, and PC5 are responsible for the explanation of $88.36 \%$ of the total information, the first two principal components were able to reflect the discrimination with a total variance of $51.09 \%$. Score plots of combinations (PC1-PC2, PC1-PC3, PC1-PC4, PC2-PC3 and PC3-PC4) were checked and found that $\mathrm{PC} 1$ and $\mathrm{PC} 2$ made higher contributions to the total variance than other principal components. Therefore, the score and loading plots were constructed using only PC1 and PC2 scores. PC1 was able to separate heat-treated blends on each storage day from control and UV-C-treated samples. UV-C-treated blends were found to have a closer relationship with the control blends. According

Table 3

Changes in physicochemical properties of LMJ blends during storage study.

\begin{tabular}{|c|c|c|c|c|c|c|c|c|c|c|}
\hline \multirow[t]{2}{*}{ Days } & \multirow[t]{2}{*}{ Treatment } & \multirow[t]{2}{*}{$\mathrm{pH}$} & \multirow{2}{*}{$\begin{array}{l}\text { Total soluble } \\
\text { solids (TSS) } \\
\text { ( }{ }^{\circ} \text { brix) }\end{array}$} & \multirow{2}{*}{$\begin{array}{l}\text { Titratable } \\
\text { acidity } \\
\text { (TA) (\%) }\end{array}$} & \multirow{2}{*}{$\begin{array}{l}\text { Absorption } \\
\text { coefficient } \\
\left(\mathrm{cm}^{-1}\right)\end{array}$} & \multirow[t]{2}{*}{ Turbidity (NTU) } & \multicolumn{4}{|l|}{ Color } \\
\hline & & & & & & & $L^{*}$ & $a^{*}$ & $\mathrm{~b}^{*}$ & $\Delta \mathrm{E}$ \\
\hline \multirow[t]{3}{*}{0} & Untreated & $3.93 \pm 0.01 b$ & $8.72 \pm 0.11 a$ & $0.51 \pm 0.01 b$ & $14.88 \pm 0.04 a$ & $278.50 \pm 2.38 b$ & $27.69 \pm 0.02 a$ & $0.06 \pm 0.01 a b$ & $2.48 \pm 0.02 a$ & $0 c$ \\
\hline & UV-C & $3.93 \pm 0.01 \mathrm{~A}$ & $8.51 \pm 0.05 \mathrm{E}$ & $0.50 \pm 0.00 \mathrm{~A}$ & $11.12 \pm 0.02 \mathrm{~A}$ & $292.75 \pm 0.96 \mathrm{~A}$ & $27.84 \pm 0.14 \mathrm{BC}$ & $0.11 \pm 0.06 \mathrm{ABCD}$ & $1.88 \pm 0.03 \mathrm{BC}$ & OC \\
\hline & Thermal & $3.92 \pm 0.01 a$ & $8.55 \pm 0.02 c$ & $0.48 \pm 0.05 a$ & $14.94 \pm 0.22 \mathrm{a}$ & $342.50 \pm 0.71 c$ & $28.07 \pm 0.01 \mathrm{ab}$ & $0.07 \pm 0.02 \mathrm{abc}$ & $1.66 \pm 0.02 b$ & Od \\
\hline \multirow[t]{3}{*}{2} & Untreated & $3.93 \pm 0.01 b$ & $8.53 \pm 0.02 b$ & $0.51 \pm 0.00 b$ & $14.62 \pm 0.08 b$ & $280.25 \pm 1.71 b$ & $27.71 \pm 0.04 a$ & $0.09 \pm 0.02 a$ & $2.53 \pm 0.02 a$ & $0.07 \pm 0.03 b$ \\
\hline & UV-C & $3.93 \pm 0.01 \mathrm{~A}$ & $8.53 \pm 0.01 \mathrm{DE}$ & $0.50 \pm 0.00 \mathrm{~A}$ & $11.16 \pm 0.18 \mathrm{~A}$ & $294.50 \pm 0.71 \mathrm{~A}$ & $27.74 \pm 0.08 \mathrm{C}$ & $0.17 \pm 0.02 \mathrm{~A}$ & $2.01 \pm 0.03 \mathrm{BC}$ & $0.15 \pm 0.03 \mathrm{BC}$ \\
\hline & Thermal & $3.92 \pm 0.01 \mathrm{a}$ & $8.56 \pm 0.02 c$ & $0.51 \pm 0.00 \mathrm{a}$ & $14.78 \pm 0.01 a$ & $347.50 \pm 0.71 \mathrm{ab}$ & $28.02 \pm 0.03 \mathrm{ab}$ & $0.06 \pm 0.02 a b c$ & $1.63 \pm 0.03 b$ & $0.10 \pm 0.05 \mathrm{~cd}$ \\
\hline \multirow[t]{3}{*}{5} & Untreated & $3.96 \pm 0.01 a$ & $8.55 \pm 0.02 b$ & $0.52 \pm 0.00 a$ & $14.92 \pm 0.00 a$ & $339.50 \pm 2.65 a$ & $27.69 \pm 0.09 a$ & $0.03 \pm 0.02 b$ & $2.20 \pm 0.04 b$ & $0.29 \pm 0.05 a$ \\
\hline & UV-C & $3.94 \pm 0.01 \mathrm{~A}$ & $8.57 \pm 0.03 \mathrm{BCD}$ & $0.51 \pm 0.01 \mathrm{~A}$ & $11.51 \pm 0.75 \mathrm{~A}$ & $294.67 \pm 1.53 \mathrm{~A}$ & $27.85 \pm 0.01 \mathrm{BC}$ & $0.15 \pm 0.04 \mathrm{AB}$ & $2.06 \pm 0.01 \mathrm{BC}$ & $0.22 \pm 0.05 \mathrm{BC}$ \\
\hline & Thermal & $3.93 \pm 0.01 a$ & $8.56 \pm 0.02 b c$ & $0.51 \pm 0.00 \mathrm{a}$ & $13.85 \pm 0.01 b$ & $344.50 \pm 0.82 b c$ & $28.13 \pm 0.01 a$ & $0.07 \pm 0.01 \mathrm{abc}$ & $1.61 \pm 0.02 b c$ & $0.08 \pm 0.03 \mathrm{~cd}$ \\
\hline \multirow[t]{2}{*}{7} & UV-C & $3.92 \pm 0.00 \mathrm{~A}$ & $8.60 \pm 0.00 \mathrm{ABC}$ & $0.51 \pm 0.01 \mathrm{~A}$ & $11.40 \pm 0.02 \mathrm{~A}$ & $297.25 \pm 1.50 \mathrm{~A}$ & $27.78 \pm 0.02 \mathrm{BC}$ & $0.15 \pm 0.02 \mathrm{~A}$ & $2.08 \pm 0.02 \mathrm{D}$ & $0.46 \pm 0.09 \mathrm{AB}$ \\
\hline & Thermal & $3.92 \pm 0.01 a$ & $8.63 \pm 0.06 a$ & $0.51 \pm 0.01 a$ & $13.28 \pm 0.01 b c$ & $347.33 \pm 1.53 \mathrm{ab}$ & $28.12 \pm 0.01 a$ & $0.09 \pm 0.02 a$ & $0.09 \pm 0.02 a$ & $0.33 \pm 0.01 \mathrm{ab}$ \\
\hline \multirow[t]{2}{*}{12} & UV-C & $3.93 \pm 0.01 \mathrm{~A}$ & $8.62 \pm 0.00 \mathrm{AB}$ & $0.51 \pm 0.00 \mathrm{~A}$ & $11.54 \pm 0.00 \mathrm{~A}$ & $299.50 \pm 1.29 \mathrm{~A}$ & $27.79 \pm 0.00 \mathrm{BC}$ & $0.12 \pm 0.02 \mathrm{ABC}$ & $2.01 \pm 0.06 \mathrm{BC}$ & $0.26 \pm 0.06 \mathrm{BC}$ \\
\hline & Thermal & $3.93 \pm 0.01 a$ & $8.63 \pm 0.02 a$ & $0.51 \pm 0.01 a$ & $13.16 \pm 0.35 c$ & $347.50 \pm 0.71 \mathrm{ab}$ & $28.13 \pm 0.08 a$ & $0.03 \pm 0.01 \mathrm{~cd}$ & $1.59 \pm 0.08 b c$ & $0.17 \pm 0.01 b c$ \\
\hline \multirow[t]{2}{*}{16} & UV-C & $3.93 \pm 0.01 \mathrm{~A}$ & $8.64 \pm 0.02 \mathrm{~A}$ & $0.51 \pm 0.01 \mathrm{~A}$ & $11.57 \pm 0.06 \mathrm{~A}$ & $299.00 \pm 0.82 \mathrm{~A}$ & $27.80 \pm 0.11 \mathrm{BC}$ & $0.11 \pm 0.01 \mathrm{ABC}$ & $2.09 \pm 0.03 \mathrm{~B}$ & $0.28 \pm 0.07 \mathrm{BC}$ \\
\hline & Thermal & $3.94 \pm 0.00 a$ & $8.62 \pm 0.01 \mathrm{ab}$ & $0.51 \pm 0.00 a$ & $13.08 \pm 0.01 c$ & $348.50 \pm 0.58 a$ & $28.03 \pm 0.01 \mathrm{ab}$ & $0.02 \pm 0.00 \mathrm{~d}$ & $1.64 \pm 0.01 b$ & $0.08 \pm 0.03 \mathrm{~cd}$ \\
\hline \multirow[t]{2}{*}{19} & UV-C & $3.93 \pm 0.02 \mathrm{~A}$ & $8.57 \pm 0.03 \mathrm{BCD}$ & $0.51 \pm 0.01 \mathrm{~A}$ & $9.73 \pm 0.15 \mathrm{~B}$ & $256.50 \pm 9.19 \mathrm{~B}$ & $28.59 \pm 0.12 \mathrm{~A}$ & $0.05 \pm 0.02 \mathrm{BCD}$ & $1.95 \pm 0.06 C$ & $0.59 \pm 0.19 \mathrm{AB}$ \\
\hline & Thermal & $3.93 \pm 0.05 a$ & $8.62 \pm 0.02 \mathrm{ab}$ & $0.51 \pm 0.00 \mathrm{a}$ & $13.17 \pm 0.02 c$ & $347.50 \pm 0.71 \mathrm{ab}$ & $28.18 \pm 0.01 a$ & $0.09 \pm 0.01 \mathrm{ab}$ & $1.61 \pm 0.06 b c$ & $0.14 \pm 0.05 \mathrm{~cd}$ \\
\hline \multirow[t]{2}{*}{26} & UV-C & $3.93 \pm 0.02 \mathrm{~A}$ & $8.54 \pm 0.02 \mathrm{DE}$ & $0.51 \pm 0.00 \mathrm{~A}$ & $9.63 \pm 0.73 \mathrm{~B}$ & $254.67 \pm 15.14 \mathrm{~B}$ & $28.06 \pm 0.25 B$ & $0.06 \pm 0.02 \mathrm{CD}$ & $2.15 \pm 0.21 \mathrm{~B}$ & $0.37 \pm 0.30 \mathrm{~B}$ \\
\hline & Thermal & $3.92 \pm 0.02 a$ & $8.60 \pm 0.02 \mathrm{abc}$ & $0.51 \pm 0.00 a$ & $13.26 \pm 0.03 b c$ & $349.00 \pm 0.00 a$ & $27.95 \pm 0.15 b$ & $0.04 \pm 0.02 \mathrm{bcd}$ & $1.54 \pm 0.02 c$ & $0.20 \pm 0.10 b c$ \\
\hline \multirow[t]{2}{*}{30} & UV-C & $3.93 \pm 0.01 \mathrm{~A}$ & $8.55 \pm 0.02 \mathrm{CDE}$ & $0.51 \pm 0.00 \mathrm{~A}$ & $9.63 \pm 0.24 \mathrm{~B}$ & $246.50 \pm 6.24 \mathrm{~B}$ & $28.09 \pm 0.16 B$ & $0.03 \pm 0.02 \mathrm{D}$ & $2.61 \pm 0.18 \mathrm{~A}$ & $0.80 \pm 0.20 \mathrm{~A}$ \\
\hline & Thermal & $3.92 \pm 0.01 a$ & $8.58 \pm 0.01 \mathrm{abc}$ & $0.50 \pm 0.00 \mathrm{a}$ & $13.31 \pm 0.01 b c$ & $349.00 \pm 0.71 a$ & $27.95 \pm 0.05 b$ & $0.04 \pm 0.02 \mathrm{~cd}$ & $1.93 \pm 0.01 a$ & $0.46 \pm 0.13 a$ \\
\hline
\end{tabular}

Tukey least significant difference test was applied. Different letters for each process show the differences in properties between days during shelf life study.

Italic lower case letters $(a, b)$ : untreated samples; CAPITAL LETTER (A,B): UV-treated samples; lower case letters (a,b): thermally treated samples. 


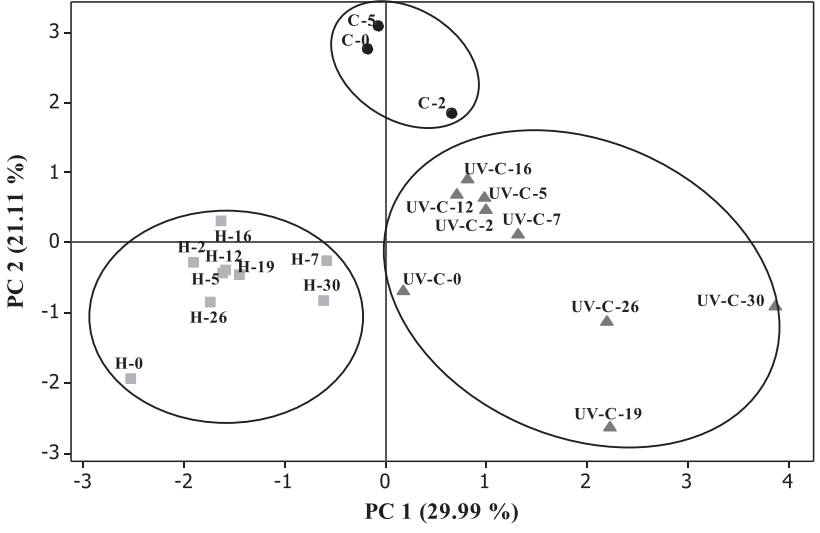

A

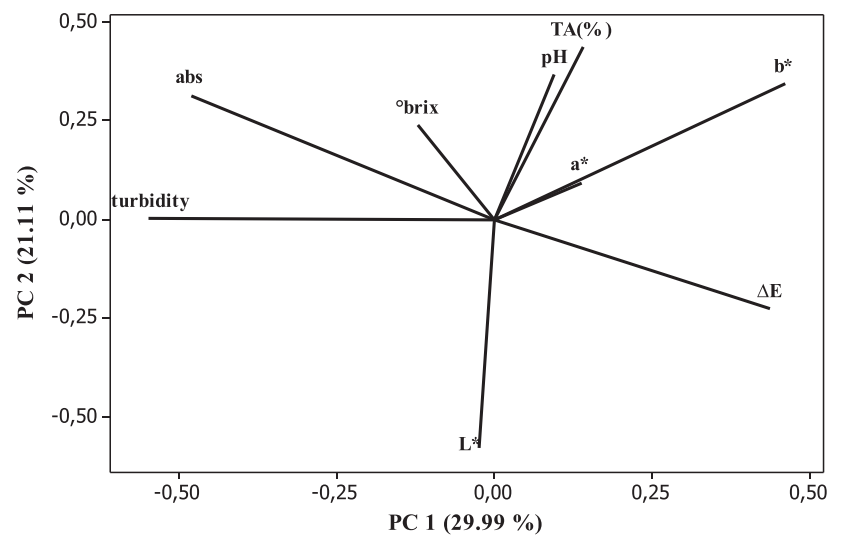

B

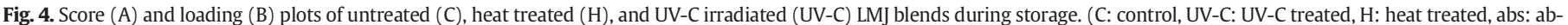
sorbance, TA: titratable acidity).

to PC2, the physicochemical properties of UV-C-treated blends stored for 19, 26 and 30 days seem to become more different from those of the control samples. Consequently, a successful discrimination among untreated, heat-treated and UV-C-treated LMJ was achieved by principal component analysis. It is also possible to conclude that UV-Ctreated LMJ blends can maintain their physicochemical properties similar to those of control blends during 16 days of storage. Turbidity, absorbance, $L^{*}$, and ${ }^{\circ}$ brix showed negative loadings, while $\mathrm{pH}, \mathrm{TA}, \mathrm{a}^{*}$, $\mathrm{b}^{*}$, and $\triangle \mathrm{E}$ had positive loadings on $\mathrm{PC} 1$. In addition, $\mathrm{L}^{*}$ and $\triangle \mathrm{E}$ displayed negative loadings, whereas $\mathrm{pH}$, ${ }^{\circ}$ brix, $\mathrm{TA}$, absorbance, $\mathrm{a}^{*}$, and $\mathrm{b}^{*}$ had positive loadings on PC2. When the loading plot was evaluated considering both PC1 and PC2, heat-treated LMJ blends could be characterized by higher turbidity and absorbance values, whereas higher $\mathrm{a}^{*}, \mathrm{~b}^{*}$, and $\Delta \mathrm{E}$ values were associated with the UV-C-irradiated blends. UV-C irradiation significantly reduced the absorption coefficient compared to the control and heat-treated blends. These findings are in accordance with the one-way analysis of variance (ANOVA). However, PCA as a multivariate statistical tool evaluates all of the data obtained during the shelf-life period.

In the present study, HCA output was computed using PCA scores from a shelf life study. The results of HCA are displayed as a dendrogram in Fig. 5, indicating that the samples within the same group are more similar to each other than to samples in different groups. HCA efficiently distinguished the control, UV-C-treated, and heat-treated LMJ blends during storage by constructing agglomerative clusters. The vertical axes highlight the distance among treatments on each storage day. The results showed that the physicochemical attributes of UV-Ctreated LMJ blends were more similar to those of the control blends than to the heat-applied samples. It is observed that UV-C-treated blends having a distance value of 7.96 were more similar to control

Table 4

PCA loadings, eigenvalues, and \% cumulative variance for the first five principal components (storage study).

\begin{tabular}{lrrrrr}
\hline Variable & \multicolumn{1}{l}{ PC1 } & \multicolumn{1}{l}{ PC2 } & \multicolumn{1}{l}{ PC3 } & \multicolumn{1}{c}{ PC4 } & \multicolumn{1}{c}{ PC5 } \\
\hline $\mathrm{pH}$ & 0.10 & 0.37 & -0.22 & -0.65 & -0.26 \\
${ }^{\circ}$ Brix & -0.12 & 0.24 & -0.30 & 0.72 & -0.08 \\
$\mathrm{TA}(\%)$ & 0.14 & 0.44 & -0.43 & 0.08 & -0.44 \\
abs (Ae) & -0.48 & 0.32 & -0.06 & -0.03 & 0.36 \\
Turbidity (NTU) & -0.55 & 0.00 & -0.12 & -0.04 & -0.25 \\
$\mathrm{~L}^{*}$ & -0.02 & -0.58 & -0.37 & -0.04 & -0.12 \\
$\mathrm{a}^{*}$ & 0.14 & 0.10 & 0.63 & 0.19 & -0.55 \\
$\mathrm{~b}^{*}$ & 0.46 & 0.35 & 0.01 & 0.07 & 0.47 \\
$\Delta \mathrm{E}$ & 0.44 & -0.23 & -0.35 & 0.10 & -0.07 \\
Eigenvalues & 2.69 & 1.89 & 1.56 & 1.06 & 0.73 \\
\% Cumulative variance & 29.99 & 51.09 & 68.45 & 80.23 & 88.36 \\
\hline
\end{tabular}

(PC: principal component, TA: titrable acidity). samples during 16 days of storage. However, the similarities between the control and non-thermally treated blends in terms of physicochemical properties were reduced after 16 days. The distance from the control was increased to 10.30 for UV-C-treated blends stored under refrigerated conditions after 19, 26, and 30 days. The distance was increased to 14.45 for heat-treated samples, showing that the heat treatment caused more of an increase in the dissimilarity of physicochemical properties compared to UV-C treatment.

\section{Conclusion}

The microbial safety of a newly formulated juice blend from Galia and Kırkagac type melon fruits was ensured by both UV-C irradiation and heat treatment. The shelf life of LMJ blends was increased from 2 days (control) to 30 days. However, UV-C treatment resulted in characteristics that were more similar to those of the control blends than the heat treated ones during storage. The multivariate data analysis was successfully applied as a tool for an overall evaluation of the shelf-life of the product. PCA clearly discriminated heat-treated and UV-Ctreated LMJ blends in terms of their physicochemical properties. In the light of these findings, UV-C irradiation has a comparable effect on microbial stability at $4{ }^{\circ} \mathrm{C}$ and better quality preservation performance than heat treatment for obtaining both shelf-stable and fresh-like LMJ blends. This would be a major advantage in juice processing because it matches consumer demand for healthy, nutritious and "natural" products.

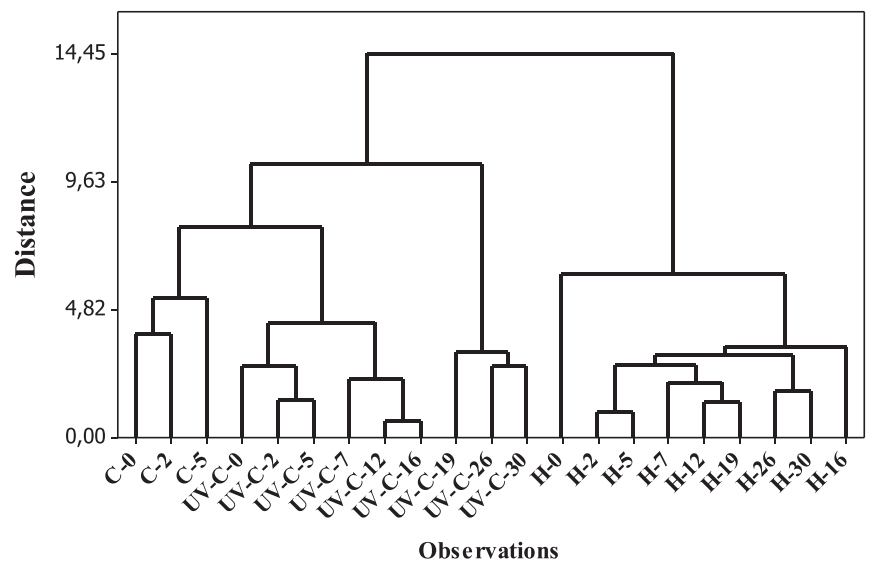

Fig. 5. Dendrogram of cluster analysis of LMJ blends (storage study). (C: control, UV-C: UV$\mathrm{C}$ treated, $\mathrm{H}$ : heat treated. Numbers indicates the day of storage). 


\section{Acknowledgment}

This study was supported by the Department of Food Engineering, Izmir Institute of Technology (IZTECH), and IZTECH Biotechology and Bioengineering Research and Application Center (BAP, 2013-IYTE-09), Izmir, Turkey.

\section{References}

Al-Jedah, J.H., \& Robinson, R.K. (2002). Nutritional value and microbiological safety of fresh fruit juices sold through retail outlets in Qatar. Pakistan Journal of Nutrition, $1(2), 79-81$.

AOAC (1990). Official methods of analysis (15th ed.). Washington, D.C.: Association of Official Analytical Chemists.

Banas, K., Banas, A., Moser, H.O., Bahou, M., Li, W., Yang, P., et al. (2010). Multivariate analysis techniques in the forensics investigation of the postblast residues by means of Fourier transform-infrared spectroscopy. Analytical Chemistry, 82(7), 3038-3044.

Bhat, R., Ameran, S.B., Voon, H.C., Karim, A.A., \& Tze, L.M. (2011). Quality attributes of starfruit (Averrhoa carambola L.) juice treated with ultraviolet radiation. Food Chemistry, 127(2), 641-644.

Caminiti, I.M., Palgan, I., Muñoz, A., Noci, F., Whyte, P., Morgan, D.J., et al. (2012). The effect of ultraviolet light on microbial inactivation and quality attributes of apple juice. Food and Bioprocess Technology, 5(2), 680-686.

Canitez, N. (2002). Pasteurization of apple cider with UV irradiation. (Master's thesis) Orono, Maine: University of Maine (Retrieved 17 December 2011, from http:// www.library.umaine.edu/theses/pdf/CanitezN2002.pdf).

CCFRA (1992). In J. Gaze (Ed.), Food pasteurisation treatments. Technical manual No. 27. Campden \& Chorleywood Food Research Association.

Chen, J.L., Zhang, J., Feng, Z., Songa, L., Wu, J., \& Hu, X. (2009). Influence of thermal and dense-phase carbon dioxide pasteurization on physicochemical properties and flavor compounds in Hami melon juice. Journal of Agricultural and Food Chemistry, 57(13), 5805-5808.

Chen, J.L., Zhang, J., Songa, L., Jiang, Y., Wu, J., \& Hu, X.S. (2010). Changes in microorganism, enzyme, aroma of Hami melon (Cucumis melo L.) juice treated with dense phase carbon dioxide and stored at $4{ }^{\circ} \mathrm{C}$. Innovative Food Science \& Emerging Technologies, 11(4), 623-629.

Chisari, M., Barbagallo, R.N., Spagna, G., \& Artes, F. (2011). Improving the quality of freshcut melon through inactivation of degradative oxidase and pectinase enzymatic activities by UV-C treatment. International Journal of Food Science and Technology, 46(3), 463-468.

Cortes, C., Esteve, M.J., \& Frígola, A. (2008). Color of orange juice treated by high intensity pulsed electric fields during refrigerated storage and comparison with pasteurized juice. Food Control, 19(2), 151-158.

Cserhalmi, Z., Sass-Kiss, A., Tóth-Markus, M., \& Lechner, N. (2006). Study of pulsed electric field treated citrus juices. Innovative Food Science E Emerging Technologies, 7(1), 49-54.

Donahue, D.W., Canitez, N., \& Bushway, A.A. (2004). UV inactivation of E. Coli 0157: H7 in apple cider: quality, sensory and shelf-life analysis. Journal of Food Processing $\mathcal{E}$ Preservation, 28(5), 368-387.

Falguera, V., Pagan, J., \& Ibarz, A. (2011). Effect of UV irradiation on enzymatic activities and physicochemical properties of apple juices from different varieties. LWT-Food Science and Technology, 44(1), 115-119.

FDA (2000). Food and Drug Administration. 21 CFR Part 179: Irradiation in the production, processing and handling of food. Federal Register, 65, 71056-71058.

FDA (2004). Food and Drug Administration. Guidance for industry: Juice HACCP hazards and controls guidance Final Guidance, March 3, 2004 (1st ed.). U.S. Department of Health and Human Services, Center for Food Safety and Applied Nutrition (CFSAN) (http:// www.fda.gov/Food/GuidanceComplianceRegulatoryInformation/GuidanceDocuments/ Juice/ucm072557.htm).

Ferrario, M., Alzamora, S.M., \& Guerrero, S. (2013). Inactivation kinetics of some microorganisms in apple, melon, orange and strawberry juices by high intensity light pulses. Journal of Food Engineering, 118(3), 302-311.

Flynn, B.B., Sakakibara, S., Schroeder, R., Bates, K.A., \& Flynn, E.J. (1990). Empirical research methods in operations management. Journal of Operations Management, 9, 250-284.

Franz, C.M.A.P., Specht, I., Cho, G.S., Graef, V., \& Stahl, M.R. (2009). UV-C-inactivation of microorganisms in naturally cloudy apple juice using novel inactivation equipment based on Dean vortex technology. Food Control, 20(12), 1103-1107.

Fratianni, A., Cinquanta, L., \& Panfili, G. (2010). Degradation of carotenoids in orange juice during microwave heating. LWT - Food Science and Technology, 43(6), 867-871.

Fredericks, I.N., Du Toit, M., \& Krügel, M. (2011). Efficacy of ultraviolet radiation as an alternative technology to inactivate microorganisms in grape juices and wines. Food Microbiology, 28(3), 510-517.

Gabriel, A.A. (2012). Inactivation of Escherichia coli 0157:H7 and spoilage yeasts in germicidal UV-C-irradiated and heat-treated clear apple juice. Food Control, 25(2), 425-432.

Gabriel, A.A., \& Nakano, H. (2009). Inactivation of Salmonella, E. coli and Listeria monocytogenes in phosphate-buffered saline and apple juice by ultraviolet and heat treatments. Food Control, 20(4), 443-446.

Gayan, E., Serrano, M.J., Monfort, S., Álvarez, I., \& Condón, S. (2012). Combining ultraviolet light and mild temperatures for the inactivation of Escherichia coli in orange juice. Journal of Food Engineering, 113(4), 598-605.
Guevara, M., Tapia, M.S., \& Gómez-López, V.M. (2012). Microbial inactivation and quality of guava and passion fruit nectars treated by UV-C light. Food and Bioprocess Technology, 5(2), 803-807.

Huang, J., Guo, X., Qiu, Y., \& Chen, Z. (2007). Cluster and discriminant analysis of electrochemical noise data. Electrochimica Acta, 53(2), 680-687.

Ibarz, A., Pagán, J., Panadés, R., \& Garza, S. (2005). Photochemical destruction of colour compounds in fruit juices. Journal of Food Engineering, 69(2), 155-160.

Kenny, O., Smyth, T.J., Hewage, C.M., \& Brunton, N.P. (2013). Antioxidant properties and quantitative UPLC-MS analysis of phenolic compounds from extracts of fenugreek (Trigonella foenum-graecum) seeds and bitter melon (Momordica charantia) fruit Food Chemistry, 141, 4295-4302.

Keyser, M., Müller, I.A., Cilliers, F.P., Nel, W., \& Gouws, P.A. (2008). Ultraviolet radiation as a non-thermal treatment for the inactivation of microorganisms in fruit juice. Innovative Food Science \& Emerging Technologies, 9(3), 348-354.

Koutchma, T. (2008). UV light for processing foods. Ozone: Science E Engineering, 30(1), 93-98.

Koutchma, T.N., Forney, L.J., \& Moraru, C.I. (2010). Ultraviolet light in food technology: Principles \& applications. United States: CRC Press.

Koutchma, T., Keller, S., Chirtel, S., \& Parisi, B. (2004). Ultraviolet disinfection of juice products in laminar and turbulent flow reactors. Innovative Food Science E Emerging Technologies, 5(2), 179-189.

Lee, W.C., Yusof, S., Hamid, N.S.A. \& Baharin, B.S. (2007). Effects of fining treatment and storage temperature on the quality of clarified banana juice. LWT - Food Science and Technology, 40(10), 1755-1764.

Lester, G. (1997). Melon (Cucumis melo L.) fruit nutritional quality and health functionality. HortTechnology, 7(3), 222-227.

Manzocco, L., Da Pieve, S., \& Maifreni, M. (2011). Impact of UV-C light on safety and quality of fresh-cut melon. Innovative Food Science E' Emerging Technologies, 12(1), 13-17.

Mazzotta, A.S. (2001). Thermal inactivation of stationary-phase and acid-adapted Escherichia coli 0157: H7, Salmonella, and Listeria monocytogenes in fruit juices. Journal of Food Protection, 64(3), 315-320.

Mitchell, M.L., \& Jolley, J.M. (1996). Research design explained. New York: HB1 College.

Mosqueda-Melgar, J., Raybaudi-Massilia, R.M., \& Martín-Belloso, O. (2007). Influence of treatment time and pulse frequency on Salmonella enteritidis, Escherichia coli and Listeria monocytogenes populations inoculated in melon and watermelon juices treated by pulsed electric fields. International Journal of Food Microbiology, 117(2), 192-200.

Mosqueda-Melgar, J., Raybaudi-Massilia, R.M., \& Martín-Belloso, O. (2008). Combination of high-intensity pulsed electric fields with natural antimicrobials to inactivate pathogenic microorganisms and extend the shelf-life of melon and watermelon juices. Food Microbiology, 25(3), 479-491.

Noci, F., Riener, J., Walkling, M., Cronin, D.A., Morgan, D.J., \& Lying, J.G. (2008). Ultraviolet irradiation and pulsed electric fields (PEF) in a hurdle strategy for the preservation of fresh apple juice. Journal of Food Engineering, 85(1), 141-146.

Pala, C. U., \& Toklucu, A.K. (2011). Effect of UV-C light on anthocyanin content and other quality parameters of pomegranate juice. Journal of Food Composition and Analysis, 24(6), 790-795.

Pala, Ç. U., \& Toklucu, A.K. (2013). Microbial, physicochemical and sensory properties of UV-C processed orange juice and its microbial stability during refrigerated storage. LWT - Food Science and Technology, 50(2), 426-431.

Pinto, F.S.T., Fogliatto, F.S., \& Qannari, E.M. (2014). A method for panelists' consistency assessment in sensory evaluations based on the Cronbach's alpha coefficient. Food Quality and Preference, 32, 41-47.

Rahn, R. O. (1997). Potassium iodide as a chemical actinometer for $254 \mathrm{~nm}$ radiation: Use of iodate as an electron scavenger. Photochemistry and Photobiology, 66(4), 450-455.

Rastogi, N.K., Raghavarao, K.S.M.S., Balasubramaniam, V.M., Niranjan, K.D., \& Knorr, D. (2007). Opportunities and challenges in high pressure processing of foods. Critical Reviews in Food Science and Nutrition, 47(1), 69-112.

Rivas, A., Rodrigoa, D., Martíneza, A., Barbosa-Cánovas, G.V., \& Rodrigo, M. (2006). Effect of PEF and heat pasteurization on the physical-chemical characteristics of blended orange and carrot juice. LWT-Food Science and Technology, 39(10), 1163-1170.

Sallam, K.I. (2007). Chemical, sensory and shelf life evaluation of sliced salmon treated with salts of organic acids. Food Chemistry, 101, 592-600.

Sánchez-Moreno, C., De Ancos, B., Plaza, L., Elez-Martínez, P., \& Cano, M.P. (2009). Nutritional approaches and health-related properties of plant foods processed by high pressure and pulsed electric fields. Critical Reviews in Food Science and Nutrition, 49 552-576.

Sew, C.C., Ghazali, H.M., Martín-Belloso, O., \& Noranizan, M.A. (2014). Effects of combining ultraviolet and mild heat treatments on enzymatic activities and total phenolic contents in pineapple juice. Innovative Food Science E Emerging Technologies, 26 511-516.

Stepansky, A., Kovalski, I., \& Perl-Treves, R. (1999). Intraspecific classification of melons (Cucumis melo L.) in view of their phenotypic and molecular variation. Plant Systematics and Evolution, 217, 313-332.

Timmermans, R.A.H., Mastwijk, H.C., Knol, J.J., Quataert, M.C.J., Vervoort, L., der Plancken, Van, et al. (2011). Comparing equivalent thermal, high pressure and pulsed electric field processes for mild pasteurization of orange juice. Part I: Impact on overall quality attributes. Innovative Food Science E Emerging Technologies, 12(3), 235-243.

Tran, M.T.T., \& Farid, M. (2004). Ultraviolet treatment of orange juice. Innovative Food Science \&' Emerging Technologies, 5(4), 495-502.

Turkish Food Codex (2002). Microbiological criteria announcement of Turkish Food Codex. No: 2001/-19. Official Gazette: 02.09.2001/24511. Ankara: Agriculture \& Village Affairs Ministry. 
Vegara, S., Martí, N., Mena, P., Saura, D., \& Valero, M. (2013). Effect of pasteurization process and storage on colour and shelf-life of pomegranate juices. LWT-Food Science and Technology, 54(2), 592-596.

Versari, A., Parpinello, G.P., \& Galassi, S. (2002). Chemometric survey of Italian bottled mineral waters by means of their labelled physico-chemical and chemical composition. Journal of Food Composition and Analysis, 15(3), 251-264.

Vervoort, L., Grauwet, T., Kebede, B.T., Van der Plancken, I., Timmermans, R., Hendrickx M., et al. (2012). Headspace fingerprinting as an untargeted approach to compare novel and traditional processing technologies: A case-study on orange juice pasteurisation. Food Chemistry, 134(4), 2303-2312.
Walkling-Ribeiro, M., Noci, F., Cronin, D.A., Lyng, J.G., \& Morgan, D.J. (2010). Shelf life and sensory attributes of a fruit smoothie-type beverage processed with moderate heat and pulsed electric fields. LWT-Food Science and Technology, 43(7), 1067-1073.

Yen, G. C., \& Lin, H. T. (2006). Effects of high pressure and heat treatment on pectic substances and related characteristics in guava juice. Journal of Food Science, 63(4), 684-687. http://dx.doi.org/10.1111/j.1365-2621.1998.tb15812.x.

Zhang, C., Trierweiler, B., Li, W., Butz, P., Xu, Y., Rüfer, C.E., et al. (2011). Comparison of thermal, ultraviolet-c, and high pressure treatments on quality parameters of watermelon juice. Food Chemistry, 126(1), 254-260. 